\title{
A survey for potentially zoonotic parasites in backyard pigs in the Bucaramanga metropolitan area, Northeast Colombia
}

\author{
Juan Carlos Pinilla1 ${ }^{(D)}$, Elsa Morales² and Angel Alberto Florez Muñoz ${ }^{1}$ (i) \\ 1. Department of Veterinary Medicine, Research Group in Agricultural Sciences, Faculty of Exact, Natural and Agricultural \\ Sciences, University of Santander, Bucaramanga, Colombia; 2. Department of Microbiology, Research Group in Clinical \\ Sciences (CliniUdes), Faculty of Health, University of Santander, Bucaramanga, Colombia. \\ Corresponding author: Juan Carlos Pinilla, e-mail: jcpinilla65@gmail.com \\ Co-authors: EM: elsita0707@hotmail.com, AAF: ang.florez@mail.udes.edu.co \\ Received: 14-09-2020, Accepted: 01-01-2021, Published online: 09-02-2021 \\ doi: www.doi.org/10.14202/vetworld.2021.372-379 How to cite this article: Pinilla JC, Morales E, Florez Muñoz AA \\ (2021) A survey for potentially zoonotic parasites in backyard pigs in the Bucaramanga metropolitan area, Northeast \\ Colombia, Veterinary World, 14(2): 372-379.
}

\begin{abstract}
Background and Aim: Backyard pigs farming is a rearing system associated with poor hygienic and sanitary conditions of the pig, often causing public health and food safety problems. Therefore, this study was conducted to investigate the occurrence of potentially zoonotic parasites in population pig reared under backyard farming in the Bucaramanga metropolitan area, Northeast Colombia.

Materials and Methods: From September to December 2019, a total of 558 fecal samples from 64 backyard pig farms were examined for the presence of enteric protozoan infection. The coprological diagnosis was done by direct examination using Lugol's iodine solution, buffered saline solution, and Kinyoun technique. In addition, blood samples were collected from 200 pigs. Serum was collected and used for the detection of Trichinella spiralis and Taenia solium cysticercosis infections, using the enzyme-linked immunosorbent assay.

Results: The overall prevalence of zoonotic protozoa in the Bucaramanga metropolitan area was $65.2 \%$, reporting $52.7 \%$ prevalence for Balantidium coli, 33.7\% for Entamoeba coli, and 5.7\% for Cryptosporidium spp. Regarding the prevalence by municipalities, there was no statistical association $(\mathrm{p}>0.05)$, indicating that the prevalence was similar in the region under study. Pigs $>7$ months of age showed to be a risk factor for $B$. coli infection, indicating that the prevalence increases with the age, while pigs raised at $>1000$ masl and access to latrines, increased infection risk for E. coli and Cryptosporidium spp. infections. In the present study, T. spiralis infection was not detected in the analyzed sera, while T. solium cysticercosis infection was found to be $40.5 \%$.

Conclusion: The high prevalence of protozoan infections and porcine cysticercosis reported in this study could be due to poor facilities, and lack of hygiene in the facilities, and suggests the possible transmission of these parasite populations between pigs and humans, thus increasing the transmission of parasites zoonotic potential. Therefore, appropriate sanitary management practices and deworming programs should be adopted to reduce the prevalence of these infectious agents.
\end{abstract}

Keywords: Colombia, cysticercosis, parasite, pigs, Trichinella, zoonotic.

\section{Introduction}

In Colombia, pig farming is a technified industry that supplies the national market; however, backyard pig farming systems have been an alternative to generate economic income in many families in different regions of the country [1]. In general, this type of rearing system is associated with low sociocultural status, poor facilities, absence of veterinarian, poor hygienic and sanitary conditions of the pig, lack of wastewater treatment, and the development of parasitic diseases, often causing public health and food safety problems, especially due to the transmission of zoonotic parasites [2].

Copyright: Pinilla, et al. Open Access. This article is distributed under the terms of the Creative Commons Attribution 4.0 International License (http://creativecommons.org/licenses/by/4.0/), which permits unrestricted use, distribution, and reproduction in any medium, provided you give appropriate credit to the original author(s) and the source, provide a link to the Creative Commons license, and indicate if changes were made. The Creative Commons Public Domain Dedication waiver (http://creativecommons.org/ publicdomain/zero/1.0/) applies to the data made available in this article, unless otherwise stated.
Many parasites affect swine health and can be transmitted to humans. As for protozoan, Balantidium coli, Entamoeba coli, and Cryptosporidium spp. are the main species [3], while Taenia solium and Trichinella spiralis represent the species of helminths with the greatest impact on public health worldwide [4]. In the Cundinamarca department, Colombia, Pulido-Villamarín et al. [5], MendozaGómez et al. [6] reported a high frequency of E. coli and $B$. coli cysts in semi-technical pig farms, while $E$. coli cyst and T. solium eggs were the most prevalent zoonotic parasites found in fecal samples from backyard pigs. Furthermore, Cazorla et al. [7] and de Guzman et al. [8] registered prevalence of $45.4 \%$ and $65 \%$ for $B$. coli infection, respectively, in pigs from rural communities of Venezuela. On the other hand, Agudelo-Florez and Palacio [9] reported a seroprevalence of $T$. solium antibodies between $2.33 \%$ and $6.84 \%$ in pigs from endemic areas of Colombia, while [10] overall seroprevalence of human cysticercosis in Colombia is reported $8.55 \%$. 
However, Trichinella spiralis has not yet been reported in Colombia [11,12].

In Colombia, there is little epidemiological information on potentially zoonotic parasites in pigs, especially in the Northeastern regions. The aim of the present research was to investigate the occurrence of potentially zoonotic protozoa, as well as, the seroprevalence of $T$. solium porcine cysticercosis and T. spiralis in pigs reared under backyard farming in the Bucaramanga metropolitan area, Northeast Colombia.

\section{Materials and Methods}

\section{Ethical approval}

This research was approved by the Institutional Ethical Committee of the University of Santander and Industrial University of Santander (ref No CIF0311-19).

\section{Study area and period}

The Santander department is located in the Colombian Northeast. This region is characterized by agricultural and cattle livestock production. According to the Colombian Agricultural Institute (ICA), the swine population census for the department was 93,000 pigs, being $85 \%$ in backyard and $40 \%$ located in the Bucaramanga metropolitan area [13]. This region comprises a geographical area of $1479 \mathrm{~km}^{2}$. Rainfall is regular throughout the year; however, more rains are experienced in October-December. Bioclimatic characteristics of the region are very similar and with a mean annual temperature of $25^{\circ} \mathrm{C}$, with little weather variation throughout the year. The altitude is between 600 and 1700 masl and the mean annual rainfall is $1040 \mathrm{~mm}$, with $78 \%$ relative humidity [14]. In general, the meat pork produced in this region is offered to local markets for internal consumption. This study was conducted from September to December 2019.

\section{Sampling design}

A cross-sectional and descriptive study was designed. Based on the ICA's inventory records, the farms were visited and selected those whose owners agreed to participate in the study. The geographical locations of the sampling site are shown in Figure-1. Sixty-four backyard pig farms located in the Bucaramanga metropolitan area, were visited from September to December 2019 (wet period). Most of the pigs sampled were crossbreeds between the Yorkshire, Landrace, and Pietrain breeds. For zoonotic protozoa, the sample size was calculated to estimate the municipality level prevalence and considering an infinite population using the formula provided by Thrusfield [15]: $\mathrm{n}=\left[\mathrm{Z} \alpha^{2} \mathrm{P}(1-\mathrm{P}] / \mathrm{d}^{2}\right.$, where " $\mathrm{n}$ " is the required sample size; " $\mathrm{Z}$ " is the multiplier from a standard normal distribution $(\alpha=1.96)$ at a probability level of 0.05 ; "p" is the expected prevalence which is most conservatively estimated to be 50 $\%$, considering that there are no reference data from pigs in the area under study; (1-P) is the probability of having no disease; and " $\mathrm{d}$ " is the maximum associated error (5\%). Therefore, a sample size of 384 pigs was determined for the study. However, to increase precision, a sample size of 558 pigs was planned. In addition, the sample size for the serological study was calculated using the same formula and with a reported prevalence by Flórez et al. [10] of $8.5 \%$ for human cysticercosis in the country, an " $n$ " of 200 animals was determined. Animals were categorized according to the age in: $\leq 2$ months, 3-6 months, 7-12 months, and $\geq 13$ months [16]. Epidemiological variables were obtained using a questionnaire administered to the owner or manager of each herd at the time of sampling. These data included sex, that is, male and females, pigs free ranging, location of the farm, pig access to latrines, dewormed, type of feed supplied to

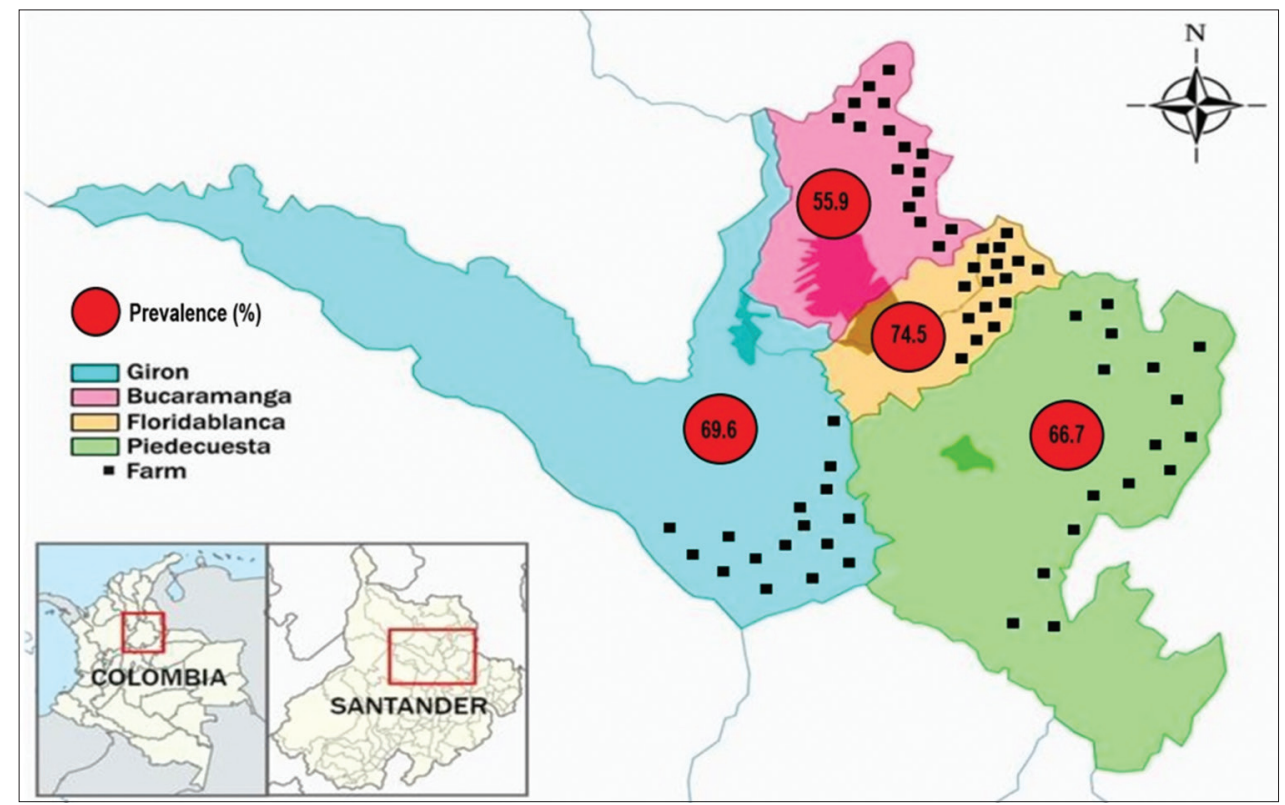

Figure-1: Bucaramanga metropolitan area map showing the sampling sites (black dots) and the overall prevalence of zoonotic protozoa [Source: https://es.wikipedia.org/wiki/\%C3\%81rea_metropolitana_de_Bucaramanga]. 
the pigs, and water source for the animals. During the sampling, no clinical signs of parasitic infection were observed in examined pigs.

\section{Sample collection and laboratory analysis}

A total of 558 fecal samples were collected from backyard pigs. Approximately $5 \mathrm{~g}$ of feces were collected directly from the rectum from each pig, using previously labeled polyethylene bags. In suckling piglets, a swab was introduced rectally to collect a small fecal sample. Samples were placed into containers filled with ice packs and immediately transported for processing in the Veterinary Clinic Research Laboratory of the University of Santander. Some of the fecal samples were immediately processed for direct examination with Lugol's iodine solution (1:5 dilutions) and buffered saline solution to determine B. coli and E. coli cysts [17]. Another portion of the fecal sample was processed by the Ziehl-Neelsen technique to detect Cryptosporidium spp. oocysts [17]. The parasitic species observed were identified by the morphology of their oocysts and cysts using a light optical microscope with $40 \times$ and $100 \times$ [17]. For serum, $5 \mathrm{~mL}$ whole blood was collected by jugular venipuncture in a sterile Vacutainer tube without ethylenediaminetetraacetic acid. The serum was separated and clarified by centrifugation at $3000 \mathrm{rpm}$ for $10 \mathrm{~min}$ and stored at $-20^{\circ} \mathrm{C}$ till the tests were performed. Serum samples were analyzed by indirect enzyme-linked immunosorbent assays (ELISA), according to the manufacturer's instructions. These tests were done using an indirect ELISA kit for the detection of anti-T. spiralis antibodies (ID Screen ${ }^{\circledR}$, Grabels, France) and Monoscreen ELISA kit for antigenic diagnosis of T. solium cysticercosis (Bio-X Diagnostics, Rochefort, Belgium).

\section{Statistical analysis}

The results were analyzed by the Chi-square test to evaluate the association between variables (municipality, sex, age group, altitude, free-ranging pigs, access to latrines, deworming, type of food, and water source) and prevalence values. Odds ratio (OR) and their confidence intervals for risk factors were obtained by univariable logistic regression analysis, taking as the reference category those with the lowest probability of risk, and leaving the others as study categories [18]. The level of significance for the analyses was $5 \%$. Calculations were made using the $\operatorname{SPSS}{ }^{\circledR}$ Statistics for Windows, (IBM, USA) version 21.0 [19].

\section{Results}

\section{Prevalence of zoonotic protozoa}

The overall prevalence of zoonotic protozoa in the Bucaramanga metropolitan area was $65.2 \%$ $(364 / 558)$. There was no statistical association $(\mathrm{p}>0.05)$ between prevalence values in the four municipalities: $55.9 \%(104 / 186)$ in Bucaramanga, $74.5 \%$ (70/94) in Floridablanca, 69.6\% (110/158) in Giron, and $66.7 \%(80 / 120)$ in Piedecuesta (Figure-1). In most $(60.1 \%)$ of the positive fecal samples, monoparasitism was evidenced, while in $39.9 \%$ of the cases, two or three protozoan parasites were found. In these cases of polyparasitism, $92.1 \%$ showed coinfection between two protozoa, being the coinfection between $B$. coli $\times E$. coli the most frequent. Overall infection rate was $52.7 \%$ for B. coli, $33.7 \%$ for E. coli, and $5.7 \%$ for Cryptosporidium spp. No statistical association was found ( $\mathrm{p}>0.05$ ) between B. coli and Cryptosporidium spp. infections and the municipalities indicating that the prevalence is present in similar proportions in the four municipalities (Table-1).

\section{Risk factors for protozoal infections}

There was a statistical association $(\mathrm{p}<0.05)$ between the positive values of $B$. coli with respect to age group. In this sense, 7-12 months and $\geq 13$ months groups showed 1.8 $(\mathrm{OR}=1.8 ; \mathrm{p}<0.05)$ and $2.9(\mathrm{OR}=2.9$; $\mathrm{p}<0.05)$ times probability for infection than other age groups. Infection rate increases with the age of the animal. The rest of the variables analyzed showed not to be a risk factor for this parasite (Table-2). In relation to Cryptosporidium spp., pigs with access to latrines showed almost 5 times higher probability for infection $(\mathrm{OR}=4.5 ; \mathrm{p}<0.05)$ than those with no access to latrines. The rest of the variables were not shown to be a risk factor for this protozoan $(\mathrm{p}>0.05)$ (Table-3). On the other hand, pigs raised $>1000$ masl, showed a higher probability of $E$. coli infection $(\mathrm{OR}=1.7$; $\mathrm{p}<0.05)$, than those kept on farms $<1000$ masl. The rest of the variables were not shown to be a risk factor for this protozoan ( $>00.05)$ (Table-4).

\section{T. spiralis and T. solium cysticercosis infections}

In general, 200 samples of swine sera were examined by ELISA, and none showed anti-T. spiralis antibodies. In contrast, the seroprevalence of porcine

Table-1: Prevalence of zoonotic protozoan obtained from the fecal samples of backyard pigs in the Bucaramanga metropolitan area, Santander, Colombia.

\begin{tabular}{|c|c|c|c|c|c|c|c|}
\hline \multirow[t]{3}{*}{ Protozoan } & \multicolumn{4}{|c|}{ Municipality } & \multirow[t]{2}{*}{ Overall } & \multicolumn{2}{|c|}{ Chi-square test } \\
\hline & $\begin{array}{l}\text { Bucaramanga } \\
\quad(n=186)\end{array}$ & $\begin{array}{l}\text { Floridablanca } \\
\quad(n=94)\end{array}$ & $\begin{array}{l}\text { Piedecuesta } \\
(n=120)\end{array}$ & $\begin{array}{c}\text { Giron } \\
(n=158)\end{array}$ & & $\chi^{2}$-value & p-value \\
\hline & Positive (\%) & Positive (\%) & Positive (\%) & Positive (\%) & Positive (\%) & & \\
\hline Balantidium coli & $88(47.3)$ & $54(57.4)$ & $62(51.7)$ & $90(57)$ & $294(52.7)$ & 2.1 & 0.55 \\
\hline Entamoeba coli & $36(19.4)$ & $46(48.9)$ & $44(36.7)$ & $62(39.2)$ & $188(33.7)$ & 14.7 & 0.002 \\
\hline Cryptosporidium spp. & $12(6.5)$ & $8(8.5)$ & $4(3.3)$ & $8(5.1)$ & $32(5.7)$ & 1.46 & 0.69 \\
\hline
\end{tabular}

Statistically significant $(p<0.05)$

Veterinary World, EISSN: 2231-0916 
Table-2: Results of logistic regression analysis for Balantidium coli: Risk factors.

\begin{tabular}{|c|c|c|c|c|}
\hline \multirow{2}{*}{$\begin{array}{l}\text { Variables } \\
\text { Age group }\end{array}$} & \multicolumn{4}{|c|}{ Balantidium coli } \\
\hline & $\mathbf{n}$ & $\%$ & p-value & OR \\
\hline$\leq 2$ months & 142 & 28.1 & & 1 \\
\hline 3-6 months & 98 & 42.8 & & 0.94 \\
\hline 7-12 months & 176 & 62.5 & & 1.8 \\
\hline$\geq 13$ months & 142 & 71.8 & 0.01 & 2.9 \\
\hline \multicolumn{5}{|l|}{ Sex } \\
\hline Male & 214 & 56.1 & & 1 \\
\hline Female & 344 & 50.6 & 0.37 & 0.8 \\
\hline \multicolumn{5}{|l|}{ Altitude } \\
\hline$<1000$ & 278 & 48.9 & & 1 \\
\hline$>1000$ & 280 & 56.4 & 0.21 & 1.3 \\
\hline \multicolumn{5}{|l|}{ Free-ranging pigs } \\
\hline No & 426 & 52.6 & & 1 \\
\hline Yes & 132 & 53 & 0.95 & 0.9 \\
\hline \multicolumn{5}{|l|}{ Access to latrines } \\
\hline No & 514 & 51.8 & & 1 \\
\hline Yes & 44 & 63.6 & 0.28 & 1.6 \\
\hline \multicolumn{5}{|l|}{ Deworming } \\
\hline No & 34 & 52.9 & & 1 \\
\hline Yes & 524 & 52.7 & 0.9 & 0.9 \\
\hline \multicolumn{5}{|l|}{ Type of food } \\
\hline Restaurant residues & 120 & 56.7 & & 1 \\
\hline Concentrate & 112 & 46.4 & & 0.66 \\
\hline Mixed & 326 & 53.4 & 0.5 & 0.87 \\
\hline \multicolumn{5}{|l|}{ Water source } \\
\hline Spring water & 130 & 46.2 & & 1 \\
\hline Deep well water & 428 & 54.7 & 0.2 & 1.44 \\
\hline Overall & 558 & 52.7 & & \\
\hline
\end{tabular}

Statistically significant $(p<0.05) . O R=$ Odds ratio, $1=$ Reference category

cysticercosis was $40.5 \%(81 / 200)$. These values were analyzed by univariable logistic regression, and according to the results obtained, there was a statistical association $(p<0.05)$ between the seropositive values for porcine cysticercosis with respect to the altitude, free-ranging pigs, access to latrines, and deworming. Therefore, free pigs and farms at $>1000$ masl showed $2(\mathrm{OR}=2 ; \mathrm{p}<0.05)$ and $2.9(\mathrm{OR}=2.9 ; \mathrm{p}<0.05)$ times, respectively, the higher probability of infection than non-free pigs confined to farms at $<1000$ masl. While access to latrines and non-dewormed pigs showed 2 $(\mathrm{OR}=2 ; \mathrm{p}<0.05)$ and almost $3(\mathrm{OR}=2.7 ; \mathrm{p}<0.05)$ times higher risk of infection of $T$. solium. There was no statistical significance between the porcine cysticercosis concerning to the other variables analyzed $(p>0.05)$ (Table-5).

\section{Discussion}

Many of the pathogens that affect pig production can be transmitted to humans. Among the porcine, parasites widely recognized as zoonotic are $B$. coli, Toxoplasma gondii, Cryptosporidium spp., T. solium and its metacestode, and T. spiralis. Therefore, the importance of these zoonoses at a global and regional level lies directly in human and animal health and indirectly in the socioeconomic development of many peoples [5]. Despite the importance of porcine zoonoses, few studies have been done in Colombia. In Latin America, the prevalence of $B$. coli infection in humans
Table-3: Results of logistic regression analysis for Cryptosporidium spp.: Risk factors.

\begin{tabular}{|c|c|c|c|c|}
\hline \multirow{2}{*}{$\begin{array}{l}\text { Variables } \\
\text { Age group }\end{array}$} & \multicolumn{4}{|c|}{ Cryptosporidium spp. } \\
\hline & $\mathbf{n}$ & $\%$ & p-value & OR \\
\hline$\leq 2$ months & 142 & 2.8 & & 1 \\
\hline 3-6 months & 98 & 2.0 & & 0.7 \\
\hline 7-12 months & 176 & 10.2 & & 3.9 \\
\hline$\geq 13$ months & 142 & 5.6 & 0.13 & 2 \\
\hline \multicolumn{5}{|l|}{ Sex } \\
\hline Male & 214 & 6.5 & & 1 \\
\hline Female & 344 & 5.2 & 0.65 & 0.7 \\
\hline \multicolumn{5}{|l|}{ Altitude } \\
\hline$<1000$ & 278 & 5 & & 1 \\
\hline$>1000$ & 280 & 6.4 & 0.62 & 1.2 \\
\hline \multicolumn{5}{|l|}{ Free-ranging pigs } \\
\hline No & 426 & 5.6 & & 1 \\
\hline Yes & 132 & 6.1 & 0.89 & 1.08 \\
\hline \multicolumn{5}{|l|}{ Access to latrines } \\
\hline No & 514 & 4.7 & & 1 \\
\hline Yes & 44 & 18.2 & 0.009 & 4.5 \\
\hline \multicolumn{5}{|l|}{ Deworming } \\
\hline No & 34 & 5.9 & & 1 \\
\hline Yes & 524 & 5.7 & 0.9 & 0.9 \\
\hline \multicolumn{5}{|l|}{ Type of food } \\
\hline Restaurant residues & 120 & 3.3 & & 1 \\
\hline Concentrate & 112 & 3.6 & & 1.07 \\
\hline Mixed & 326 & 7.4 & 0.38 & 2.3 \\
\hline \multicolumn{5}{|l|}{ Water source } \\
\hline Spring water & 130 & 3.1 & & 1 \\
\hline Deep well water & 428 & 6.5 & 0.3 & 2.2 \\
\hline Overall & 558 & 5.7 & & \\
\hline
\end{tabular}

Statistically significant $(p<0.05)$. OR=Odds ratio,

$1=$ Reference category

ranges between $0.5 \%$ and $2.1 \%$, being low compared to other intestinal infections by protozoa. However, Mendoza-Gómez et al. [6] revealed 10\% infection for B. coli and $60 \%$ for $E$. coli in workers from semi-technified farms located in the department of Cundinamarca, Colombia. On the other hand, Flórez et al. [10] determined a seroprevalence of $1.96 \%$ of human cysticercosis in the department of Santander, Colombia.

\section{Prevalence of zoonotic protozoa}

The overall prevalence of zoonotic protozoa found in the four municipalities was similar, since the temperature and humidity conditions in the zone, the management in most of the farms, as well as the programs in the control of infectious agents are similar in the four municipalities [20]. Furthermore, the high prevalence found in this study indicates the absence of hygienic and sanitary conditions in the examined farms, where some risk factors may have favored the dissemination and transmission of protozoan parasites among animals. The results obtained in this research agree with those reported by several authors $[7,16,21,22]$ who found similar values of prevalence in backyard pig farming from Colombia, Venezuela, Mexico, and Brazil.

The present study found that $B$. coli was the most prevalent zoonotic protozoan $(52.7 \%)$ followed by E. coli $(33.7 \%)$. These results obtained agree with those 
Table-4: Results of logistic regression analysis for Entamoeba coli: Risk factors.

\begin{tabular}{|c|c|c|c|c|}
\hline \multirow{2}{*}{$\frac{\text { Variables }}{\text { Age group }}$} & \multicolumn{4}{|c|}{ Entamoeba coli } \\
\hline & $\mathbf{n}$ & $\%$ & p-value & OR \\
\hline$\leq 2$ months & 142 & 32.4 & & 1 \\
\hline 3-6 months & 98 & 28.6 & & 1 \\
\hline 7-12 months & 176 & 35.2 & & 1.2 \\
\hline$\geq 13$ months & 142 & 36.6 & 0.8 & 1.2 \\
\hline \multicolumn{5}{|l|}{ Sex } \\
\hline Male & 214 & 33.6 & & 1 \\
\hline Female & 344 & 33,7 & 0.9 & 1 \\
\hline \multicolumn{5}{|l|}{ Altitude } \\
\hline$<1000$ & 278 & 28.1 & & 1 \\
\hline$>1000$ & 280 & 39.3 & 0.04 & 1.7 \\
\hline \multicolumn{5}{|l|}{ Free-ranging pigs } \\
\hline No & 426 & 32.4 & & 1 \\
\hline Yes & 132 & 37.9 & 0.41 & 1.2 \\
\hline \multicolumn{5}{|l|}{ Access to latrines } \\
\hline No & 514 & 34.2 & & 1 \\
\hline Yes & 44 & 27.3 & 0.5 & 0.7 \\
\hline \multicolumn{5}{|l|}{ Deworming } \\
\hline No & 34 & 35.3 & & 1 \\
\hline Yes & 524 & 33.6 & 0.88 & 0.99 \\
\hline \multicolumn{5}{|l|}{ Type of food } \\
\hline Restaurant residues & 120 & 40 & & 1 \\
\hline Concentrate & 112 & 21.4 & & 0.41 \\
\hline Mixed & 326 & 35.6 & 0.08 & 0.86 \\
\hline \multicolumn{5}{|l|}{ Water source } \\
\hline Spring water & 130 & 33.8 & & 1 \\
\hline Deep well water & 428 & 33.6 & 0.9 & 0.9 \\
\hline Overall & 558 & 33.7 & & \\
\hline
\end{tabular}

Statistically significant $(p<0.05)$. OR=Odds ratio, $1=$ Reference category

recorded by de Guzman et al. [8] and Pinto et al. [23] who revealed similar values of prevalence in outdoor pigs. However, the results obtained differ from those reported by Mendoza-Gómez et al. [6] who found 5\% prevalence for $B$. coli in farms from Cundinamarca department, Colombia. The prevalence of E. coli in the present study was $33.7 \%$, and this result agrees with those reported by Mendoza-Gómez et al. [6] who found $40 \%$ prevalence in pigs from Cundinamarca department. Although E. coli do not cause infection, their presence indicates the fecal-oral transmission in the host, which is an indicator for the general assessment of the hygiene status of the animals. According to the results obtained, the E. coli prevalence was higher $(48.9 \%)$ in pigs from Floridablanca municipality. This region is located at medium altitudes (1000-1700 masl), with mean annual temperature $\left(25-30^{\circ} \mathrm{C}\right)$ long the year, with prolonged periods of rain and average precipitation rates between 1100 and $1400 \mathrm{~mm}$, which are favorable climatological conditions for this protozoan and increased risk of infection for the animals. Moreover, this result could be caused by the ingestion of contaminated water or food or by immunosuppression in the animals due to factors like stress associated with overcrowding.

About Cryptosporidium spp., the prevalence rate found was $5.7 \%$. This result agrees with those by Mendoza-Gómez et al. [6] who found similar prevalence values in semi-technified farms.
Table-5: Seroprevalence of porcine cysticercosis $T$. solium antigen in backyard pigs from the Bucaramanga metropolitan area.

\begin{tabular}{|c|c|c|c|c|}
\hline \multirow[t]{2}{*}{ Variable } & \multirow[t]{2}{*}{$\mathbf{n}$} & \multicolumn{3}{|c|}{ T. solium antigen } \\
\hline & & $\%$ & p-value & OR \\
\hline \multicolumn{5}{|l|}{ Municipality } \\
\hline Bucaramanga & 91 & 33 & & 1 \\
\hline Floridablanca & 29 & 51.7 & & 1.4 \\
\hline Piedecuesta & 45 & 37.8 & & 0.6 \\
\hline Giron & 35 & 54.3 & 0.087 & 2.04 \\
\hline \multicolumn{5}{|l|}{ Age group } \\
\hline$\leq 2$ months & 46 & 41.3 & & 1 \\
\hline 3-6 months & 61 & 32.8 & & 0.6 \\
\hline 7-12 months & 50 & 48 & & 1.4 \\
\hline$\geq 13$ months & 43 & 41.9 & 0.43 & 0.9 \\
\hline \multicolumn{5}{|l|}{ Sex } \\
\hline Male & 73 & 49.3 & & 1 \\
\hline Female & 127 & 35.4 & 0.054 & 0.56 \\
\hline \multicolumn{5}{|l|}{ Altitude } \\
\hline$<1000$ & 121 & 33.9 & & 1 \\
\hline$>1000$ & 79 & 50.6 & 0.02 & 2 \\
\hline \multicolumn{5}{|l|}{ Free-ranging pigs } \\
\hline No & 41 & 22 & & 1 \\
\hline Yes & 159 & 45.3 & 0.007 & 2.9 \\
\hline \multicolumn{5}{|l|}{ Access to latrines } \\
\hline No & 69 & 27.5 & & 1 \\
\hline Yes & 131 & 47.3 & 0.03 & 2 \\
\hline \multicolumn{5}{|l|}{ Deworming } \\
\hline Yes & 8 & 0 & & 1 \\
\hline No & 192 & 42.2 & 0.02 & 2.7 \\
\hline \multicolumn{5}{|l|}{ Type of food } \\
\hline Restaurant residues & 32 & 46.9 & & 1 \\
\hline Concentrate & 48 & 50 & & 1.9 \\
\hline Mixed & 120 & 35 & 0.14 & 0.6 \\
\hline \multicolumn{5}{|l|}{ Water source } \\
\hline Spring water & 30 & 36.7 & & 1 \\
\hline Deep well water & 170 & 41.2 & 0.64 & 1.2 \\
\hline Overall & 200 & 40.5 & & \\
\hline
\end{tabular}

Statistically significant $(p<0.05)$. OR=Odds ratio, $1=$ Reference category, $T$. solium $=$ Taenia solium

Cryptosporidiosis is a disease of high zoonotic importance, known as a public health problem that affects mainly people that interact with farm animals daily. Therefore, it is important to demonstrate the presence of this pathogen with zoonotic potential, to take measures such as strengthening the breeding management of pigs and improving the sanitary control to avoid the spread of pathogens [24].

\section{Risk factors for protozoan infections}

The access to latrines in some of the examined farms showed to be a risk factor for Cryptosporidium spp. infection. These results agree with those reported by Thomas et al. [25] who found a positive correlation between parasitic infection and interactions with latrines, and a moderate positive correlation between coccidia infection and home range area [25]. These results could be explained since this pathogen is transmitted through the fecal-oral route in humans and animals, usually through the ingestion of contaminated water or food with feces [26]. Probably, the contact with infective human fecal material by pigs is an important requisite for the successful maintenance of the parasite lifecycle; therefore, it would be to think stands to reason 
that keeping free-ranging pigs in contact with latrines, would increase the risk of the pigs in acquiring this parasitic infection [25]. In developing countries, the environmental risk factors and routes of transmission for Cryptosporidium spp. infection are not well defined. Despite the numerous surveillance studies reported, few investigations have been conducted on the source of infection. However, contamination of water supplies and infection of domestic animals, lacking adequate municipal water and sewage services, and using a field or latrine for defecation in human communities were correlated with a higher risk of cryptosporidiosis [26]. Regarding the age factor, pigs $>7$ months of age showed higher prevalence values for $B$. coli than those younger ( $<7$ months). This could be explained because young pigs, especially suckling piglets and weaner, are usually less affected by this parasitic infection, but soon became infected either from the mother or from coprophagy of residual fecal material. In general, however, the prevalence increases in pigs with age [27]. Altitude factor showed to be a risk factor for E. coli, since all the backyard farms in the Floridablanca municipality are $>1000$ masl.

\section{$T$. spiralis and $T$. solium cysticercosis infections}

In the present study, no T. spiralis antibodies were detected in the porcine sera analyzed, which could indicate that this parasite does not circulate in the backyard pigs population of the region under study. These results agree with those reported by Chaparro-Gutiérrez et al. [28] and Pulido-Villamarín et al. [29] who did not report the infection by this nematode in pigs from different regions of Colombia. The results obtained in the present study disagree with those reported by several authors [30,31], where this zoonotic pathogen is endemic in Argentina and Chile, and it's circulating among a large number of animals including pigs. These results also differ from those found by Pozio [32] who reported that anti-Trichinella antibodies were detected in sera from domestic pigs in different regions of Bolivia. Despite serology can occasionally yield false-positive results ChávezLarrea et al. [33], it would be warranted that any seropositive result may be confirmed by the artificial digestion assay [28]. A study showed that when the recommended protocol for the ELISA test is strictly followed, a negative result is an excellent indicator of the absence of infection, with a specificity of $98.29 \%$ [34]. Despite our results, it would be important to maintain a continuous vigilance of the parasite in our country, considering that the endemic situation in Argentina, Chile, and Bolivia, in addition to the effects of globalization, could be possible mechanisms for the spread of the parasite for our backyard pigs and other animals. In this sense, serological tests for the diagnosis of this parasite have the advantage of detecting mild infections $(<1$ larva per gram of muscle) and they can perform on the living animal. However, these methods do not replace direct detection methods that are carried out in slaughterhouses to control this zoonosis due to its high costs, but they are suitable for control programs on farms as well as for epidemiological studies of the cycle jungle disease [11].

The seroprevalence of $T$. solium cysticercosis was $40.5 \%$ which is similar to the seroprevalence of porcine cysticercosis found in areas where the disease is considered hyperendemic [35]. Few studies reveal the presence of porcine cysticercosis in Colombia; however, our results agree with those reported by Molano et al. [36] who demonstrated a similar serological prevalence in semi-technical and backyard farms in the Boyaca department, Colombia. Our study revealed that the altitude, no deworming, and free-ranging pigs increased the risk of being seropositive to porcine cysticercosis $T$. solium. In this sense, the coexistence of poor sanitary conditions and free-ranging pigs certainly plays an important role in the circulation of T. solium infection in this region. Free-roaming of pigs is known to be an important risk factor for T. solium infection of pigs [37]. Probably, pigs free-ranging when they have access to latrines, could have higher contact with $T$. solium eggs, and therefore, increase the odds of cysticercosis transmission risk to the pig itself, to other pigs, even humans [25]. However, other studies consider that the presence of latrines is a protective factor in decreasing the seroprevalence of porcine cysticercosis and is not surprising as the use of latrines has been proposed to control cysticercosis worldwide by several authors $[37,38]$.

The pig, as an intermediate host, plays an important role in T. solium taeniasis, due to its coprophagic habits as it sometimes has access to latrines, where it can feed on excrement of an infected host (man), so backyard pigs are considered of high risk, especially if not kept in proper hygiene and feeding conditions and if their meat is consumed without proper cooking [39]. Therefore, the results obtained allow us to affirm that porcine cysticercosis represents a risk for public health in the region under study, since socioeconomic and cultural aspects are involved in the life cycle of this parasite, with human activities being those directly involved in reproduction and dispersal of this parasite [40].

\section{Conclusion}

It concluded that the high prevalence of protozoan infections and porcine cysticercosis reported in this study could be due to poor facilities, and lack of hygiene in the facilities, and suggests the possible transmission of these parasite populations between pigs and humans, thus increasing the transmission of potentially zoonotic parasites. Therefore, appropriate sanitary management practices and deworming programs should be adopted to reduce the prevalence of these infectious agents.

\section{Authors' Contributions}

JCP conceived and designed the research. JCP and AAF conducted the sample collection. JCP and 
EM processed samples in the Microbiology Research Laboratory. JCP carried out the data analysis and writing of the manuscript. AAF edited the manuscript. All the authors read and approved the submitted version of the manuscript.

\section{Acknowledgments}

The authors thank the staff of Microbiology Research Laboratory of the University of Santander, Colombia, for their help in the analysis of the serum samples. The authors thank the University of Santander, Colombia, for financial support of this project No. CIF 0311-19.

\section{Competing Interests} interests.

The authors declare that they have no competing

\section{Publisher's Note}

Veterinary World remains neutral with regard to jurisdictional claims in published map and institutional affiliation.

\section{References}

1. PorkColombia. (2017) Investment Projects Report Developed During the Year 2017. Management Report for the Year 2017. Available from: https://www. miporkcolombia.co/wp-content/uploads/2018/09/ InformeGesti\%C3\%B3nA\%C3\%B1o2017.pdf. Retrieved on 11-07-2020.

2. Owen, I.L. (2005) Parasitic zoonoses in Papua New Guinea. J. Helminthol., 79(1): 1-14.

3. Solaymani-Mohammadi, P. and Petri, W. Jr. (2006) Zoonotic implications of the swine-transmitted protozoal infections. Vet. Parasitol., 140(3-4): 189-203.

4. World Health Organization. (2017) Teniasis/Cysticercosis Descriptive note $\mathrm{N}^{\circ} 376$. WHO. Available from: http:// www.who.int/mediacentre/factsheets/fs376/es. Retrieved on $15-05-2020$.

5. Pulido-Villamarín, A., Barbosa-Buitrago, A., HernándezGallo, N., Mendoza-Gomez, M., Ortiz-Rincón, I. and García-Fonseca, S. (2013) Potencial zoonotic parasites found in six swine farms of Cundinamarca, Colombia. Neotrop. Helminthol., 7(1): 51-63.

6. Mendoza-Gómez, M., Pulido-Villamarín, A., BarbosaBuitrago, A. and Aranda-Silva, M. (2015) Presence of gastrointestinal parasites in swine and human of four swine production farms in Cundinamarca-Colombia. Rev. MVZ. Córdoba., 20(1): 5014-5027.

7. Cazorla, D.J., Acosta, M.E., Tortolero, J.L. and Morales, P. (2013) Prevalence of porcine enteroparasites in a rural community on the Paraguaná city, Falcón state, Venezuela. Rev. Cien. FCV LUZ, 23(1): 19-25.

8. de Guzman, R., Nessi, A., González, H., Hernández, M., Galindo, M., Dorta, A., Wagner, C., Vethencourt, M. and de Pérez, G. (2013) Balantidium spp in Pigs and Their Breeders: Prevalence in Communities of TWO STATES of Venezuela. VITAE Academia Biomédica Digital, No. 54. Available from: https://vitae.ucv.ve/pdfs/VITAE_4767.pdf. Retrieved on 31-01-2021.

9. Agudelo-Florez, P. and Palacio, L.G. (2003) Prevalence of Taenia solium antibodies in humans and in pigs in an endemic area of Colombia. Rev Neurol., 36(8): 706-709.

10. Flórez, A., Pastrán, S., Vargas, N., Enríquez, Y., Peña, A., Benavidez,A., Villareal, A., Rincón, C., Garzón, I., Muñoz, L., Guasmayan, L., Valencia, C., Parra, S. and Hernández, N. (2013) Cysticercosis in Colombia. Seroprevalence study
2008-2010. Acta. Neurol. Colomb., 29(2): 73-86.

11. Laverde, L., Builes, L. and Masso, C. (2009) Detection of Trichinella spiralis in pigs slaughtered in two processing plants in the municipality of Bello. CES J., 4(2): 47-53.

12. Moreno, S. and León, J. (2015) Trichinella spiralis epidemiology in pigs slaughtered in a processing plant in the Bogotá savanna. Zoociencia, 2(1): 8-9.

13. ICA. (2017) Instituto Colombiano Agropecuario. Vigilancia epidemiológica. Censo Pecuario Nacional-2017. Available from: https://www.ica.gov.co/Areas/Pecuaria/Servicios/ Epidemiologia-Veterinaria/Censos-2016/Censo-2017.aspx. Retrieved on 12-07-2020.

14. Gobernación de Santander. (2017) Municipios del Departamento de Santander. Available from: http://www. santander.gov.co/d/index.php/es/mainmeneldpto/mendepmun2017. Retrieved on 20-08-2020.

15. Thrusfield, M. (2007) Veterinary Epidemiology. $3^{\text {rd }}$ ed. Blackwell Science Ltd., Oxford. p624.

16. de Araújo, H.G., da Silva, J.T., Álvares, F.B., Ferreira, L.C., Azevedo, S.S. and Vilela, V.L. (2019) Prevalence and risk factors associated with swine gastrointestinal nematodes and coccidia in the semi-arid region of Northeastern Brazil. Trop. Anim. Health. Prod., 52(1): 379-385.

17. Figueroa-Castillo, J.A., Jasso-Villazul, C., LiébanoHernández, E., Martínez-Labat, P., Rodríguez-Vivas, R.I. and Zárate-Ramos, J.J. (2015) In: Rodríguez-Vivas, R.I., editor. Coproparasitoscopic Examination: Techniques for the Diagnosis of Parasites with Importance in Public and Veterinary Health. AMPAVE-CONASA, México, DF.

18. Aguayo, C. and Lora, M. (2007) Step-by-step Logistic Regression: Multivariate Analysis. DocuWeb-fabis. DotNúm 0702013. Andalusian Beturia Foundation for Health Research, Huelva. p1-35.

19. IBM. (2012) SPSS Statistics for Windows, Version 21.0. IBM Corporation, Armonk, NY.

20. Cordero, C.M. and Rojas, F. (1999) Parasitología Veterinaria. $1^{\text {st }}$ ed. McGraw-Hill, España. p323.

21. Herrera, Y., Almanza, M., Ensuncho, C., Goméz, L. and Galeano, M. (2015) Coprological determination of the parasitofauna in creole pigs (Sus scrofa domestica) in the department of Córdoba, Colombia. Rev. Colom. Cienc. An., 7(2): 160-164.

22. Kú, R., Trejo, W., Aguilar, A., Belmar, R. and Castillo, J. (2013) Gastrointestinal parasitism in the backyard Mexican hairless pig in the state of Yucatan, Mexico. Rev. Colom. Cienc. An., 6(1): 17-24.

23. Pinto, J.M., Costa, J.O. and Souza, J.C. (2007) Occurrence of endoparasites in pigs reared in Itabuna, Bahia, Brazil. Ciên. Vet. Nos. Tróp., 10(2): 79-85.

24. Zheng, S., Li, D., Zhou, C., Zhang, S., Wu, Y., Chang, Y., Chen, Y., Huang, J., Ning, C., Zhang, G. and Zhang, L. (2019) Molecular identification and epidemiological comparison of Cryptosporidium spp. Among different pig breeds in Tibet and Henan, China. BMC. Vet. Res., 15(1): 101.

25. Thomas, L., de Glanville, W., Cook, E. and Fèvre, E. (2013) The spatial ecology of free-ranging domestic pigs (Sus scrofa) in western Kenya. BMC. Vet. Res., 9(1): 46.

26. Chacín-Bonilla, L., Barrios, F. and Sanchez, Y. (2008) Environmental risk factors for Cryptosporidium infection in an island from Western Venezuela. Mem. Inst. Oswaldo Cruz Rio. de Janeiro., 103(1): 45-49.

27. Schuster, F.L. and Ramirez-Avila, L. (2008) Current world status of Balantidium coli. Clin. Microbiol. Rev., 21(4): 626-638.

28. Chaparro-Gutiérrez, J., Pozio, E., Gómez-Morales, M., López, A., Mejia, J., Zambrano, C., Piedrahita, D. and Villar, D. (2018) A preliminary survey of Trichinella spp. In pigs raised under controlled housing conditions in Colombia: 2014-2016. Parasite, 25(18): 2-5.

29. Pulido-Villamarín, A., Castañeda-Salazar, R., MendozaGómez, M. and Vivas-Díaz, L. (2019) Presence of antibodies against some pathogens of zoonotic interest in four 
pig farms in Cundinamarca, Colombia. Rev. Inv. Vet. Perú., 30(1): 446-454.

30. Ortega-Pierres, M.D., Arriaga, C. and Yépez-Mulia, L. (2000) Epidemiology of trichinellosis in Mexico central and South America. Vet. Parasitol., 93(3-4): 210-225.

31. Pozio, E. (2014) Searching for Trichinella: Not all pigs are created equal. Trends Parasitol., 30(1): 4-11.

32. Pozio, E. (2007) World distribution of Trichinella spp. Infections in animals and humans. Vet. Parasitol., 149(1-2): 3-21.

33. Chávez-Larrea, M.A., Dorny, P., Moeller, L., BenítezOrtiza, W., Barrionuevo-Samaniego, M., RodríguezHidalgo, R., RonRomána, J., Proaño-Péreza, F., Victor, B., Brandt, J., Kapel, C. and Borchgrave, J. (2005) Survey of porcine trichinellosis in ecuador. Vet. Parasitol., 132(1-2): 151-154.

34. Gómez-Morales, M.A., Ludovisi, A., Pezzotti, P., Amati, M., Cherchi, S., Lalle, M., Pecoraro, F. and Pozio, E. (2009) International ring trial to detect anti-Trichinella IgG by ELISA on pig sera. Vet. Parasitol., 166(9-4): 241-248.

35. Jayashi, C.M., Arroyo, G., Lightowlers, M.W., García, H.H., Rodríguez, S. and Gonzalez, A.E. (2012) Seroprevalence and risk factors for Taenia solium cysticercosis in rural pigs of Northern Peru. PLoS Negl. Trop. Dis., 6(7): e1733.

36. Molano, D.P., Andrade, R. and Giraldo, J. (2009) Serological determination of porcine cysticercosis in the slaughter plant of the municipality of Sogamoso (Boyaca). Rev. Colomb. Cienc. Pecu., 22(3): 416-429.

37. Assana, E., Amadou, F. and Thys, E. (2010) Pig-farming systems and porcine cysticercosis in the North of Cameroon. J. Helminthol., 84(4): 441-446.

38. Sarti, E., Flisser, A., Schantz, P.M., Gleizer, M. and Loya, M. (1997) Development and evaluation of a health education intervention against Taenia solium in a rural community in Mexico. Am. J. Trop. Med. Hyg., 56(2): 127-132.

39. Flórez, A., Pastrán, S., Peña, A., Benavides, A., Villarreal, A., Rincón, C., Garzón, I., Muñoz, L. and Guasmayan, L. (2011) Cysticercosis in Boyacá, Colombia: Seroprevalence study. Acta. Neurol. Colomb., 27(1): 9-18.

40. Giraldo Forero, J., Riaño, M. and Vásquez, L. (2017) Determination of the seroprevalence of swine cysticercosis and identification of human teniasis in people raising in the urban area of the municipality of Coyaima, Tolima. Med. J., 25(1): 31-45.

\section{$* * * * * * * *$}

